\title{
Verða ný lyf í boði fyrir sjúklinga árið 2016?
}
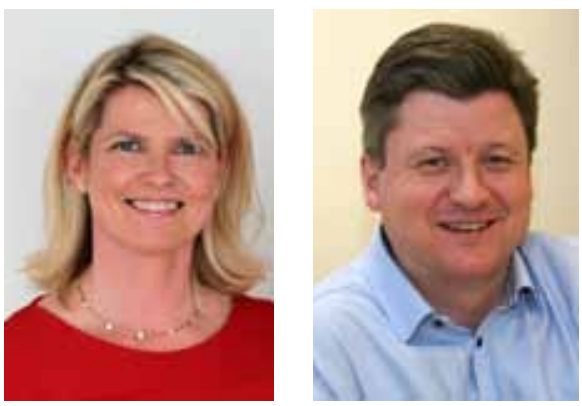

Gerður

Gröndal

lyf- og gigtarlæknir, Landspítala

\section{Gunnar Bjarni}

Ragnarsson

yfirlæknir lyflækninga krabbameina, Landspítala
Frumvarp til fjárlaga fyrir árið 2016 liggur nú fyrir, fjárveitingin sem ætluð er til svokallaðra S-merktra lyfja er 6472 milljónir kr. miðað við 6488 milljónir kr. fyrir árið 2015. Í frumvarpinu lækkar framlagið sem nemur 210 milljónum króna milli ára vegna spár um gengisforsendur. Á móti kemur raunhækkun framlags um 3\% frá fyrra ári, eða um 195 milljónir kr. til að mæta kostnaðarhækkun vegna magnaukningar. En mun pessi upphæð duga til pess að veita fullnægjandi lyfjameðferð fyrir sjúklinga á næsta ári?

Á undanförnum árum hafa orðið gríðarlegar framfarir í lyfjameðferð margra sjúkdóma, meðal annars krabbameina, blóðsjúkdóma, augnsjúkdóma og gigtarsjúkdóma. Óhætt er að halda pví fram að dýr lyf séu notuð á varfærnislegan hátt hérlendis. Á Íslandi parf klínískur sérfræðingur að sækja um meðferð með S-merktum lyfjum til lyfjanefndar Landspítala fyrir hvern og einn sjúkling. Oft er um að ræða langvarandi sjúkdóma sem kalla á meðferð árum saman og fylgst er með árangri með- ferðarinnar með endurteknu árangursmati sem sent er til lyfjanefndar spítalans.

Svo dæmi séu tekin af notkun pessara lyfja pá hefur meðferð með nýju líftæknilyfjunum gerbreytt lífi fjölda gigtarsjúklinga, haldið peim vinnufærum og bætt lífsgæði peirra. Notkun pessara lyfja eykst árlega um um pað bil 10\% hjá pessum sjúklingahópi pví sjúklingum fjölgar par sem um langtímameðferð er að ræða. Fjöldi nýrra lyfja hefur verið próaður og árangur lyfjameðferðar batnað. Petta hefur orðið til pess að margir krabbameinssjúklingar geta vænst lengra og betra lífs prátt fyrir að greinast með ólæknandi sjúkdóm. Ljóst er að kostnaður mun aukast vegna pessarar lyfjapróunar. Ef ekki verður hægt að taka upp ný krabbameinslyf í takt við próunina, er ljóst að pjónusta við krabbameinssjúklinga mun versna og lifun peirra verða skemmri en í peim löndum sem við viljum bera okkur saman við.

Vegna takmarkaðra fjárheimilda hefur ekki verið unnt að innleiða mikilvæg lyf sem eru nú pegar í notkun á Norðurlöndunum. Árið 2014 voru einungis tekin upp fáein ný S-merkt lyf og á pessu ári er sömu sögu að segja, einungis örfá ný lyf hafa verið tekin í notkun, pað er yfirleitt pau lyf sem auka ekki kostnað og koma í staðinn fyrir önnur sambærileg lyf. Vegna fjárskorts eru fjöldatakmarkanir á einni ákveðinni viðurkenndri lyfjameðferð. Mörg ný lyf bíða innleiðingar en grundvallarreglan er sú að Landspítalinn óskar einungis eftir pví að ríkið taki pátt í að greiða lyf sem hafa ótvírætt sannað gildi sitt í klínískum rannsóknum.

Hin Norðurlöndin eru almennt að fjölga peim lyfjum sem sjúkrahúsin eru bæði fjárhagslega og faglega ábyrg fyrir. Hérlendis varð hins vegar sú breyting síðastliðið vor að öll umsýsla varðandi S-merkt lyf er ekki lengur einungis á hendi Landspítala, par sem einnig má nú afgreiða pau S-merktu lyf sem notuð eru utan sjúkrahúsa í öllum apótekum. Рað liggur einnig ljóst fyrir að Lyfjastofnun stefnir að pví að leggja niður S-merkingu á mörgum pessara lyfja í nánustu framtíð. Eins og reglugerðir eru í dag má vænta að pessar breytingar geti leitt af sér kostnaðarauka án pess að lyfjameðferð aukist eða batni, meðal annars vegna hækkunar á álagningu pessara lyfja og fleiri pátta. Vissulega er pörf á að endurskoða flókna umsýslu lyfjamála af og til en við breytingar er einnig nauðsynlegt að vega og meta pann kostnað og ábata sem breytingar hafa í för með sér.

Раð er áhyggjuefni ef lyfjameðferð sjúklinga með alvarlega sjúkdóma verður ekki sambærileg pví sem tíðkast í löndum sem við kjósum að bera okkur saman við. Miðað við ofangreint frumvarp til fjárlaga er ljóst að svigrúm til upptöku nýrra lyfja verður áfram mjög takmarkað og hætta á að greiðslupátttöku í gagnlegri lyfjameðferð sem eykur kostnað, verði hafnað.

Við nefndarmenn í lyfjanefnd Landspítala vonum að fjárveitingavaldið og heilbrigðisyfirvöld taki ofangreindar athugasemdir til greina og auki fjárveitingu til S-merktra lyfja fyrir árið 2016. Аð öðrum kosti er ekki ljóst hvort hægt verður að halda lyfjameðferð sambærilegri við pað sem tíðkast á Norðurlöndunum.

Will there be new drugs for patients in Iceland 2016?

Gerður Gröndal, MD PhD, Specialist in Internal Medicine and Rheumatology, Landspitali, University Hospital

Gunnar Bjarni Ragnarsson, MD, Chief of Medical Oncology, Landspitali, University Hospital 